УДК 658.87:339.162.3

Іваненко Л.М., кандидат економічних наук, доцент кафедри маркетингу, Донецький національний університет імені Василя Стуса

\title{
СУЧАСНІ ПРОЦЕСИ РЕАГУВАННЯ РИТЕЙЛУ НА ГЛОБАЛЬНІ ТЕНДЕНЦІЇ КУПІВЕЛЬНОГО ПОВОДЖЕННЯ
}

У статті розглянуто сучасні процеси, що відбуваються на ринку глобального ритейлу. Проведено аналіз світових тенденцій купівельного поводження та їх розвиток у майбутній перспективі.

Запропоновано схему процесу стратегічного розвитку глобального ритейлу. Цей процес включає такі складові: планування сценарію розвитку глобального ритейлу, що здійснюється на основі дослідження рушійних сил споживача; процес воронки продажу, котрий допомагає зрозуміти та задовольнити очікування, потреби та бажання ринку споживачів; мозковий штурм для ключових ідей, що пов'язані з майбутніми сценаріями розвитку глобального ритейлу, і полягає в тому, що рушійні сили надають сильний вплив на повсякденний ритм і на купівельні особливості споживача.

Визначено основні сценарії майбутнього розвитку магазинів роздрібної торгівлі: багатоканальний та багатоформатний підходи. Встановлено фактори успіху розвитку магазину на основі системи роздрібного досвіду, до яких належать інновації на рівні продукту, збуту, технологій, а також інтуїція, кооперація та креативність роздрібної мережі.

Ключові слова: глобальний ритейл, купівельне поводження, стратегічний розвиток, інновації, роздрібні магазини.

Рис. 2, табл. 1, літ. джерел 12

\section{Иваненко Л.М. \\ СОВРЕМЕННЫЕ ПРОЦЕССЫ РЕАГИРОВАНИЯ РИТЕЙЛА НА ГЛОБАЛЬНЫЕ ТЕНДЕНЦИИ ПОКУПАТЕЛЬСКОГО ПОВЕДЕНИЯ}

В статье рассмотрены современные процессы, происходящие на рынке глобального ритейла. Проведен анализ мировых тенденций покупательского поведения и рассмотрены возможности их развития в будущей перспективе..

Предложена схема процесса стратегического развития глобального ритейла. Этот процесс включает следующие составляющие: планирование сценария развития глобального ритейла, который осуществляется на основе исследования движущих сил потребителя; процесс воронки продаж, который помогает понять и удовлетворить ожидания, потребности и желания рынка потребителей; мозговой штурм для ключевых идей, связанных с будущими сценариями развития глобального ритейла, и заключается в том, что движущие силы осуществляют сильное влияние на повседневный ритм и на покупательские особенности потребителя.

Определены основные сценарии будущего развития магазинов розничной торговли - многоканальный и многоформатный подходы. Установлены факторы успеха развития магазина на основе системы розничного опыта, к которым относятся инновации на уровне продукта, сбыта, технологий, а также интуиция, кооперация и креативность розничной сети.

Ключевые слова: глобальный ритейл, покупательское поведение, стратегическое развитие, инновации, розничные магазины. 


\section{Ivanenko L. MODERN PROCESSES OF THE RETAILER'S RESPONDING TO GLOBAL TENDENCIES OF THE PURCHASE BEHAVIOUR}

The article considers the modern processes taking place in the global retail market. The analysis of the world's purchase behaviour tendencies has been conducted, and possibilities of their development in future perspective have been considered.

The scheme of the process of the global retail strategic development has been offered. This process includes the following components: planning a scenario of the global retail development, which is carried out on the basis of the study of the consumer's driving forces; the funnel process, which helps to understand and satisfy expectations, needs and desires of the consumer market; brainstorming for key ideas related to future scenarios of the global retail development and lies in the fact that the driving forces exercise the strong influence on the daily rhythm and the consumer's purchasing characteristic properties.

The main scenarios of the retail store future development have been defined - multichannel and multi-format approaches. The factors of success for the development of the store have been established on the basis of the retail experience system, which include innovations at the level of a product, sales, technologies, as well as intuition, cooperation and creativity of the retail network. retail stores

Keywords: global global retail, purchase behaviour, strategic development, innovation,

Постановка проблеми. Роздрібна торгівля стрімко розвивається в умовах сучасної світової економіки. При цьому відомі світові компанії постійно розробляють та впроваджують нові цікаві ідеї у практичну діяльність своїх роздрібних магазинів. Ці ідеї покликані не відобразити поточні тенденції та процеси купівельного поводження, а визначити шляхи реагування ритейлу на них. Майбутній успіх торгівельної компанії залежить, перш за все, від здатності інтегрувати будь-які нові процеси в існуючи концепції або використовувати їх у якості міцної основи для розробки нових концепцій. Для цього потрібні зрозумілі процедури і ефективно сплановані стратегії розвитку.

Аналіз останніх досліджень. Проблемам розвитку глобального ритейлу та використанню інструментів торгової політики світових компаній присвячені роботи багатьох зарубіжних і вітчизняних учених: Бермана Б. [1], Кента Т., Омара О. [2], Чорної М., Кушнір Т., Волосова А. [3], Федулової Л. [4], Козлової О. [5] та інших. У роботах цих авторів розглянуто сучасний стан і тенденції змін глобального ритейлу та умови, що визначають його розвиток; світові тенденції реалізації маркетингових стратегій торговельними транснаціональними компаніями; характерні риси трансформаційних процесів в роздрібній торгівлі, які висвітлюють еволюцію торгових форматів.

Виділення невирішеної проблеми. Не зважаючи на вагомий внесок даних учених у вивчення питання глобальних тенденцій у сучасному ритейлі та особливостей купівельного поводження, існують певні питанні, що потребують більш глибокого аналізу та деталізації.

Постановка завдання. Ціль дослідження полягає у з'ясуванні сучасних тенденцій глобального ритейлу та визначенні стратегій його пріоритетного розвитку у взаємозв'язку з купівельним поводженням.

Виклад основного матеріалу. Існуючі кризові явища в середовищі функціонування торгівельних підприємств, посилення конкурентної боротьби, а також важко прогнозовані дії окремих гравців на ринку ритейла зі всією гостротою зосереджують увагу практично кожного підприємства на проблемі виживання в складній 
економічній ситуації. Тому в рамках вирішення насущної проблеми найбільшого інтересу набуває дослідження особливостей і тенденцій ринку ритейла.

Останні десять років зміни сучасної системи ритейлу відбувається досить стрімко. Багато дослідників прогнозують і подальші трансформації в даному секторі глобальної економіки. Поведінка споживачів та інформаційні технології стали основними факторами даних модифікацій. I в цьому ключі торгові організації повинні знайти для себе найбільш прийнятні формати в системі розподілу продукції, а також підвищення споживчої цінності товарів і послуг, що продаються.

За даними дослідження «Deloitte Global» можна виділити основні процеси, які відбуваються на сучасному глобальному ринку ритейлу [6].

По-перше, мінімальний роздрібний дохід найбільших роздрібних компаній світу протягом останніх років неухильно збільшувався. За 2006-2016 роки цей показник збільшився на 2,33 млрд. долл. (на 97\%).

По-друге, Свропа втрачає місце в Азіатсько-Тихоокеанському регіоні та деяких країнах, що розвиваються. Боротьба 3 європейськими економіками, вихід Великобританії з Свропейського Союзу та слабкі показники деяких великих ритейлерів у Свропі за останні роки, включаючи продуктовий сектор, призвели до того, що частка Європи за останні 10 років в «ТОП 250» зменшилася з 39,4\% до 33,8\%.

По-третє, роздрібні торговці з Китаю, Японії, а також деякі гравці з ринків, що розвиваються в Африці, на Середньому Сході, та решта країн АзіатськоТихоокеанського регіону набирають обертів. Їх частка роздрібних доходів у «ТОП 250» (за методикою «Deloitte Global») збільшилась на 5,9 \% за період з 2006 по 2016 роки (рис. 1).

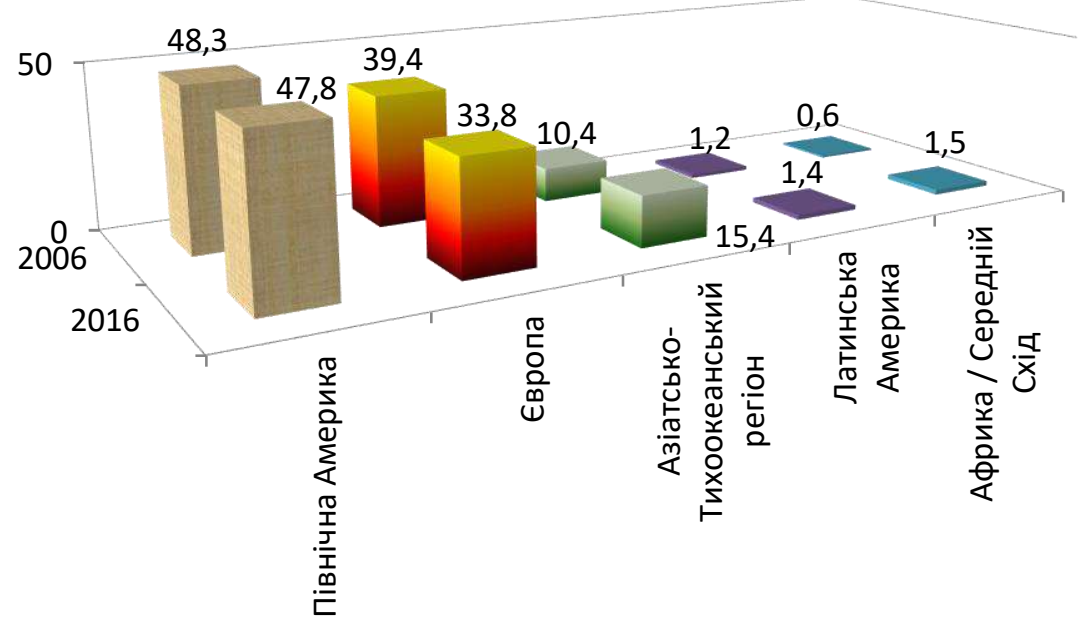

Рис. 1 - Порівняння частки роздрібних доходів по регіонах світу за 2006-2016 pp., \%

Джерело: складено автором на основі [6].

По-четверте, 10 найбільших роздрібних торговців у світі продовжують створювати найбільшу частку з продажів, що становить 30,7\% від загального обсягу продаж ритейлерів, що входять в «ТОП 250» [6] (табл. 1). 
Таблиця 1

Роздрібні доходи «ТОП 10» ритейлерів у 2006-2016рр., млрд. дол.

\begin{tabular}{|c|l|l|c|c|c|}
\hline $\begin{array}{l}\text { Ранг } \\
\text { ТОП } \\
250\end{array}$ & \multicolumn{1}{|c|}{$\begin{array}{c}\text { Найменування } \\
\text { компанії }\end{array}$} & $\begin{array}{c}\text { Країна } \\
\text { походження }\end{array}$ & $\begin{array}{c}\text { Роздрібний } \\
\text { дохід у } \\
2006 \text { р., } \\
\text { млрд. долл. }\end{array}$ & $\begin{array}{c}\text { Роздрібний } \\
\text { дохід у 2016 р., } \\
\text { млрд. долл. }\end{array}$ & $\begin{array}{c}\text { Темпиросту, } \\
\text { п }\end{array}$ \\
\hline 1 & Wal-Mart Stores, Inc. & США & 344,992 & 485,873 & 40,8 \\
\hline 2 & $\begin{array}{l}\text { Costco Wholesale } \\
\text { Corporation }\end{array}$ & США & 58,963 & 118,719 & 101,4 \\
\hline 3 & The Kroger Co. & США & 66,111 & 115,337 & 74,5 \\
\hline 4 & Schwarz Group & Німеччина & 52,422 & 99,256 & 89,3 \\
\hline 5 & $\begin{array}{l}\text { Walgreens Boots } \\
\text { Alliance, Inc. }\end{array}$ & США & 47,409 & 97,058 & 104,7 \\
\hline 6 & Amazon.com, Inc. & США & 10,711 & 94,665 & 783,8 \\
\hline 7 & The Home Depot, Inc. & США & 90,837 & 94,595 & 4,1 \\
\hline 8 & Aldi Group & Німеччина & 50,010 & 84,923 & 69,8 \\
\hline 9 & Carrefour S.A. & Франція & 97,861 & 84,131 & $-14,0$ \\
\hline 10 & $\begin{array}{l}\text { CVS Health } \\
\text { Corporation }\end{array}$ & США & 40,286 & 81,100 & 101,3 \\
\hline
\end{tabular}

Джерело: складено автором на основі [6, 7].

Компанія «Wal-Mart» зберігає свої позиції світового лідера у рейтингу глобальних ритейлерів вже понад 20 років. Лише 4 («Wal-Mart», «Kroger», «Home Depot», «Carrefour») з 10 найкращих роздрібних торговців у 2016 році перебували у списку «ТОП 10» у 2006 році. Компанія «Amazon.com» злетіла з 70 місця у рейтингу «ТОП 250» в 2006 році на шосте місце в 2016 році. Зараз ії роздрібний дохід складає близко 100 млрд. долл. Таким чином, для світової економіки настав період відносно сильного зростання та сприятливих обставин. Темпи зростання пришвидшилися в країнах Свропи та в Японії, стабілізувалися в Китаї та США і відновилися для багатьох інших ринків, що розвиваються.

Зміни, що відбуваються в світі, неминуче торкаються сфери роздрібної торгівлі. Щоб вижити в конкурентній боротьбі, глобальний ритейл миттєво реагує на коливання споживчих настроїв та очікувань. Тому дуже важливо не тільки відслідковувати глобальні тенденції та процеси, але також бути здатним з максимальною швидкістю інтегрувати будь-які нові процеси в існуючі концепції або використовувати їх в якості міцної основи для розробки нових концепцій торгівлі.

Проведення аналізу тенденцій купівельного поводження та прогноз їх розвитку у майбутній перспективі має велике значення для роздрібної торгівлі. Можна виділити наступні глобальні тенденції купівельного поводження:

1. Різноманітність. Більшість стереотипів, які передавалися від покоління до покоління, руйнуються, існуючі умовності розмиваються. Це відбувається в двох напрямках. По-перше, в суспільстві все більше і більше поширюється емансипація, i, як наслідок, ролі чоловіка і жінки міняються. По-друге, багатокультурне суспільство впливає на існуючі стандарти і цінності. Взаєморозуміння і участь не завжди притаманні людству від природи, в результаті формується потреба триматися певних принципів і прагнути до безпеки. Це змінює традиції в сімейному житті і в сфері харчування, способах ведення господарства, роботі та проведенні дозвілля. 
2. Віртуальність. «Бери від життя все» - це основний девіз більшості споживачів. Завдяки новим цифровим технологіям люди все частіше переміщують свої життєві цінності у віртуальний світ. Соціальні мережі вселяють в них почуття свободи та відсутності будь-якого контролю. Що стосується їхніх інтересів, то вони хочуть бути почутими і брати активну участь у віртуальних бесідах. Люди все частіше обмінюються інформацією зі своїми віртуальними друзями. У цих спільнотах проблеми повсякденного життя часто виносяться на обговорення. Все обертається навколо підвищеної прозорості, причому «миттєве задоволення» і «миттєве розчарування» - це дві сторони однієї медалі.

3. Життєздатність. Обізнаність у даній темі є центральним елементом. Люди знають більше і роблять більш усвідомлений вибір. Парадокс полягає в тому, що це ставить їх перед багатьма життєвими дилемами: залишатися здоровими, відчувати більше насолоди і комфорту, але при цьому бути відповідальними, працездатними і дисциплінованими. Люди хочуть виглядати молодше і розуміють, що втомилися від своїх соціальних ролей. Крім відмінностей в рівні доходу і освіти, буде все більше посилюватися розрив між тими, хто стоїть вище і нижче на сходах життєздатності. Складається нова ієрархія споживчих цінностей. Цей процес посилить фінансовий тиск на систему охорони здоров'я.

4. Нова ідея роботи. У минулому для індивідуума пропонувалися широкі можливості для просування по кар'єрних сходах при належному старанні і зусиллях. Великі компанії пропонували довічне працевлаштування. Кожне наступне покоління ставало більш успішним у фінансовому плані, ніж попереднє. В результаті економічної переорієнтації, що сталася по всьому світу, всі моделі менеджменту компаній переходять на гнучкі виробничі системи. Це несе величезні наслідки для виробничих відносин у сфері промисловості. Іншими словами, постійної довічної роботи більше не існує. Саме тому люди стали витрачати гроші більш усвідомлено.

5. Прозорість та соиіальна відповідальність. Подальше збільшення поінформованості і прагнення пізнати навколишній світ має на увазі, що все більше людей не бажає змиритися зі своїм становищем на даний момент часу. Підвищена прозорість та соціальна відповідальність грають важливу роль у житті кожного індивідуума. I, як наслідок, «соціальний вплив» кожної людини стає частиною громадської думки. Приблизно 66\% споживачів прагнуть витрачати на покупку більше, якщо компанія дотримується екологічних та етичних норм [8]. Отже, споживач не тільки задовольняє свої потреби, але й зміню світ на краще. Це істотно впливає на роль організацій, брендів і моделей ведення бізнесу.

Таким чином, в найближчі роки кожен з вищезазначених чинників певною мірою вплине на основну частину суспільства. Це ймовірно призведе до істотної зміни життєвих цінностей людини взагалі і споживача зокрема. Люди почнуть шукати нові маяки, котрі допоможуть їм вирішити дилему при прийнятті рішень. Саме тоді сильні бренди ритейла, засновані на відомих і знайомих цінностях, будуть здатні посилити свій вплив на цільові ринки покупців.

Майбутній успіх роздрібного магазину полягає в тому, щоб діяти так, як важливо для цільового ринку покупців. Для цього потрібні зрозумілі процедури і ефективно сплановані стратегії розвитку ритейлу.

У процесі стратегічного розвитку глобального ритейлу приймаються рішення, що мають суттєві наслідки для напряму розвитку роздрібної компанії. 3 урахуванням нестатків та потреб споживачів, тенденцій купівельного поводження запропоновано наступну схему процесу стратегічного розвитку глобального ритейлу (рис. 2).

Цей процес включає такі складові: 
- планування сценарію розвитку глобального ритейлу, що здійснюється на основі дослідження рушійних сил споживача;

- процес воронки продажу, котрий допомагає зрозуміти та задовольнити очікування, потреби та бажання ринку споживачів;

- мозковий штурм для ключових ідей, що пов'язані з майбутніми сценаріями розвитку глобального ритейлу, і полягає в тому, що рушійні сили здійснюють сильний вплив на повсякденний ритм й на купівельні особливості споживача.

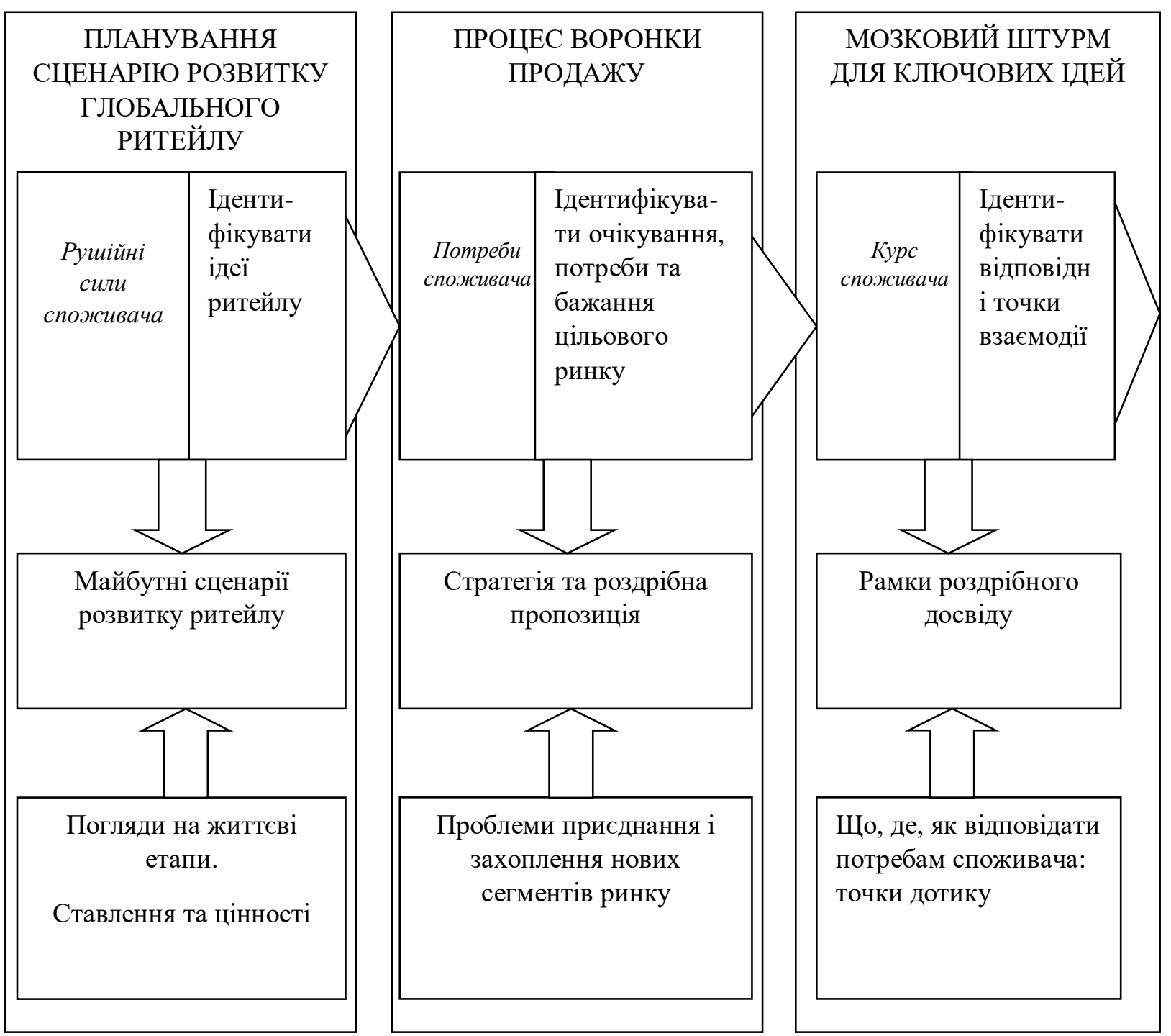

Рис. 2 - Схема процесу стратегічного розвитку глобального ритейлу Джерело: складено автором

Досвід відвідування споживачем магазину не тільки визначає купівельну поведінку в певний момент, але також впливає на формування відповідного образу магазину у споживача. Тому найважливіше - це правильно визначити точки дотику. При цьому необхідно розуміти і знати, що це буде означати для споживача в залежності від місця і обставин, відповідно до потреб на даний момент, або ж коли, як і де здійснюється процес покупки та споживання товару чи послуги. 
У процесі розробки стратегії розвитку ритейлу важливим аспектом виступає планування сценарію майбутнього розвитку магазинів роздрібної торгівлі. Можна виділити два пріоритетних сценарію розвитку: інтегрований багатоканальний та багатоформатний. Ці сценарії розвитку, як правило, розробляються та діють паралельно. Перший сценарій характеризується можливістю використання різних каналів зв'язку для встановлення контакту з клієнтами. До таких каналів відносяться: оффлайн- і онлайнмагазини, мобільні пристрої, телебачення. Їх головне призначення - максимально оптимізувати процес здійснення покупок споживачем. Для багатоканального ритейлу необхідні наступні компоненти: достатня та достовірна інформація про продукти, оновлення в реальному часі інформації про складські запаси, конкурентні ціни, продумана система повернення товару, а також ефективний зворотній зв'язок (відгуки користувачів, коментарі в соцмережах). «Багатоканальні покупці» (ті, хто роблять покупки оффлайн, онлайн і з мобільних пристроїв) витрачають на 76\% більше, ніж ті, хто купує тільки у фізичних магазинах: в середньому \$ 1643 проти \$ 943 на людину за сезон різдвяних продажів [9].

Другий сценарій розвитку ритейлу, багатоформатний підхід, що заснований на певних пропозиціях в різних місцях і характеризується реагуванням на купівельні особливості та потреби конкретного місця розташування [10]. Поведінка споживачів в певних регіонах визначає процес розробки пропозиції. Ефективний форматний підхід пов'язує конкретне місце розташування з «часовим» фактором: терміном між купівлею і моментом споживання. Сучасний споживач дуже уважно відстежує ціни, однак час або його відсутність $є$ дуже важливим аргументом для прийняття рішення про покупку. Зручність магазину крокової доступності, навіть незважаючи на те, що ціни там дещо вищі, а асортимент менше, є особливо привабливим для окремих груп споживачів. Однак, це може бути застосовано, якщо схема організації магазину і асортимент продукції адаптовані під споживчі очікування в конкретному місці. Абсолютно ясно, що для цього потрібні інвестиції для кардинальної зміни схеми організації магазину і заміни однобрендової філософії на стратегію диференціації, що орієнтована на формат роздрібної торгівлі.

Таким чином, багатоформатний сценарій розвитку передбачає багато варіантів $\mathrm{i}$ можливостей. Для багатьох мереж це означає можливості використання сили роздрібного бренду, що напрацьована в минулому, для формування мережі магазинів у всіх сферах ритейлу. Отже, багатоканальний та багатоформатний сценарії розвитку глобального ритейлу надають нові можливості для росту навіть на переповненому ринку. Але необхідно враховувати, що неможливо слідувати кожній тенденції, яка існує на цільовому ринку покупців. Поведінка покупців є одночасно локальною і глобальною. Споживачів цікавить здорова низькокалорійна їжа, але в той же самий час вони вдаються до крайніх заходів, забуваючи про калорії. Вони ретельно вивчають відсоток вмісту жиру в йогурті та набирають у кошик хліб, булочки й печиво. Тому ритейлери розробляють різні напрямки роздрібної концепції в залежності від груп клієнтів та їх поводження.

Роздрібним магазинам слід обрати одну з мега-тенденцій, визначити іiі ключові фактори та внести необхідні зміни в концепцію роздрібної торгівлі. А для цього необхідно чітко уявляти фактори успіху розвитку магазину. Аналіз результатів дослідження міжнародних аудиторських компаній KPMG i Deloitte $[11,6]$ показав, що існує не так багато насправді інноваційних факторів успіху магазину, котрі базуються на основі роздрібного досвіду. На це є декілька причин: ритейлери бояться втратити існуючих клієнтів; у них обмежений бюджет на дослідження і розробки, якими управляє відділ маркетингу; вони бояться ділитися інформацією. 
Це призводить до того, що ринок ритейлу значно удосконалюється на рівні: печі Remia;

- продукту. Наприклад, новий смак батончика Тwix або соуси для мікрохвильової

- збуту. Наприклад, використання інтернет-магазинів та web-сайтів для реалізації товарів та послуг компанії;

- технології. Наприклад, роздрібний гігант «Масу's» використовує технологію RFID у своєму філіалі «SoHo Bloomingdale». Завдяки використанню даної технології точність обробки даних про наявність товару на складі підвищилася на 97\% [12].

Справжній успіх з'являється тільки тоді, коли всі три рівня поєднані. Але переваг успіху недостатньо для нововведення. Залежно від інструментарію, що використовується магазином роздрібної торгівлі, шанси на успіх оцінюються від $2 \%$ до $20 \%$. Це означає, що мінімум 80\% нової продукції не досягає мети, для якої вона була призначена. Крім того, можна виділити три складових інноваційного успіху ритейлу: інтуїція, процес кооперації та креативність.

Висновки. Визначено, що для світового ритейлу настав період відносно сильного зростання та сприятливих обставин. Темпи зростання пришвидшилися в країнах Свропи та в Японії, стабілізувалися в Китаї та США і відновилися для багатьох інших ринків, що розвиваються. 10 найбільших роздрібних торговців у світі продовжують створювати найбільшу частку з продажів, що становить $30,7 \%$ від загального обсягу продаж ритейлерів, що входять в «ТОП 250».

Аналіз світових тенденцій купівельного поводження дозволив виявити рушійні сили, які відіграють істотну роль у розвитку ринку глобального ритейлу. До таких факторів належать: різноманітність, віртуальність, життєздатність, нова ідея роботи, прозорість та соціальна відповідальність.

Запропоновано схему процесу стратегічного розвитку глобального ритейлу. Цей процес включає такі складові: планування сценарію розвитку глобального ритейлу, що здійснюється на основі дослідження рушійних сил споживача; процес воронки продажу, котрий допомагає зрозуміти та задовольнити очікування, потреби та бажання ринку споживачів; мозковий штурм для ключових ідей, що пов'язані з майбутніми сценаріями розвитку глобального ритейлу, і полягає в тому, що рушійні сили надають сильний вплив на повсякденний ритм й на купівельні особливості споживача. Досвід відвідування споживачем магазину не тільки визначає купівельну поведінку в певний момент, але також впливає на формування відповідного образу магазину у споживача.

Визначено основні сценарії майбутнього розвитку магазинів роздрібної торгівлі: багатоканальний та багатоформатний підходи. Ці сценарії розвитку, як правило, розробляються та діють паралельно. Для багатоканального ритейлу необхідні наступні компоненти: достатня і достовірна інформація про продукти, оновлення в реальному часі інформації про складські запаси, конкурентні ціни, продумана система повернення товару, а також ефективний зворотній зв'язок. Багатоформатний підхід, заснований на певних пропозиціях в різних місцях і характеризується реагуванням на купівельні особливості та потреби конкретного місця розташування. Багатоканальний та багатоформатний сценарії розвитку глобального ритейлу надають нові можливості для росту навіть на переповненому ринку.

Встановлено фактори успіху розвитку магазину на основі системи роздрібного досвіду, до яких належать інновації на рівні продукту, збуту, технологій, а також інтуїція, кооперація та креативність роздрібної мережі. 


\section{СПИСОК ВИКОРИСТАНИХ ДЖЕРЕЛ}

1. Берман Б. Розничная торговля: стратегический поход. М.: Изд. дом "Вильямс", 2007. $1181 \mathrm{c}$.

2. Кент Т., Омар О. Розничная торговля. М.: ЮНИТИ-ДАНА, 2007. 719 с.

3. Чорна М.В, Кушнір Т.Б., Волосов А.М. Світовий рітейл: тенденції розвитку та конкурентні позиції. Науковий вісник Ужгородського університету. 2016. Серія Економіка. Випуск 1 (47). Т. 1. С. 293-300.

4. Федулова Л. Вплив світових технологічних трендів на формування «розумного» рітейлу. Зовнішня торгівля: економіка, фінанси, право. 2018. № 1. С. 5-21.

5. Козлова О. А. Изменение форматов розничной торговли. Научно-мето- дический электронный журнал «Концепт». 2017. № S1. URL: http://e-koncept.ru/2017/470005.htm.

6. Global Powers of Retailing 2018: Transformative change, reinvigorated commerce. URL: http://www.deloitte.com/globalpowersretailing.2018.

7. Deloitte. 2008 global powers of retailing. Standing out from the crowd. URL: http://www.deloitte.com/consumerbusiness. 2008.

8. Гаспарян С. Ритейл майбутнього: чого очікувати у 2018 році. URL: https://biz.nv.ua/ukr/experts/serhij-hasparjan/ritejl-majbutnoho-choho-ochikuvati-u-2018rotsi-2464924.html.

9. Тингелстэд Дж. Многоканальный ритейл: взгляд основателей всемирной бизнес-сети для ритейлеров. URL: https://ain.ua/2015/05/26/mnogokanalnyj-ritejl-vzglyad-osnovatelejvsemirnoj-biznes-seti-dlya-ritejlerov.

10. Іваненко Л.М. Багатоформатна маркетингова стратегія управління підприємством роздрібної торгівлі. Економіко-правова парадигма розвитку сучасного суспільства: наукове-періодичне видання за підсумками IV Міжнародної науково-практичної конференції викладачів, аспірантів і студентів. Вінниця. 2015. С. 21 - 24.

11.KPMG презентує звіт «Глобальні тренди ритейлу 2018». URL: https://home.kpmg.com/ua/uk/home/media/press-releases/2018/04/kpmg-presents-retailreport-2018.html

12. Bloomingdale's and others say RFID works. URL: http://www.rfidjournal.com/ articles/view?10673 